\title{
The effect of temperature on the germination of Melocactus violaceus Pfeiff. (Cactaceae), a threatened species in restinga sandy coastal plain of Brazil
}

\author{
LUIZ R. ZAMITH ${ }^{1}$, DENISE D. CRUZ ${ }^{2}$ and BÁRBARA T.T. RICHERS ${ }^{3}$ \\ ${ }^{1}$ Universidade Federal Fluminense, Instituto de Biologia, \\ Departamento de Biologia Geral, Caixa Postal 100436, 24020-971 Niterói, RJ, Brasil \\ ${ }^{2}$ Universidade Federal da Paraíba, CCEN, Cidade Universitária, 58059-900 João Pessoa, PB, Brasil \\ ${ }^{3}$ Instituto de Desenvolvimento Sustentável Mamirauá, Av. Brasil, 197, Juruá, Caixa Postal 38, 69470-000 Tefé, AM, Brasil
}

Manuscript received on April 8, 2011; accepted for publication on May 14, 2012

\begin{abstract}
Melocactus violaceus is an endangered species due to habitat destruction and the overcollection of this species for ornamental use. The aim of this study was to test the effect of different temperatures on the germination of $M$. violaceus. Three treatments were conducted: a constant temperature of $25^{\circ} \mathrm{C}$, a $20-35^{\circ} \mathrm{C}$ alternating temperature, both inside germination chamber, and an alternating temperature under room temperature (mean temperature ranged from $25-37^{\circ} \mathrm{C}$ ). The final seed germination rates at the alternating temperature treatments were not significantly different $(65 \%$ in the seed germinator and $62.5 \%$ at room condition). However, both treatments with alternating temperatures had significantly higher germination rates compared to the treatment kept at the constant temperature (8\%). Our study showed that alternating temperatures between 20 and $37^{\circ} \mathrm{C}$ provides satisfactory conditions to induce a high percentage of seed germination of $M$. violaceus, without the passage of seeds through the digestive tract of its natural disperser, the lizard Tropidurus torquatus. This condition contributes to efficiently producing seedlings that can be reintroduced into conservation areas or used as ornamentals that may help reduce the overcollection of the remaining native populations.
\end{abstract}

Key words: Cactaceae, conservation, germination, Melocactus violaceus, restinga, temperature.

\section{INTRODUCTION}

Restingas and mangroves are vegetation formations associated with the Atlantic Forest (Rizzini 1979, Scarano 2002), which has been reduced to $7.5 \%$ of its original size, and is considered one of the 25 biodiversity hotspots, and one of the five most threatened regions in the world (Myers et al. 2000). Restinga is composed of sandy coastal plains of marine origin and comprises beach ridges, dunes,

Correspondence to: Luiz Roberto Zamith

E-mail:1rzamith@gmail.com inter-ridge and inter-dune depressions, swamps, marshes and lagoons (Lacerda et al. 1993). The plant communities that occur in these topographic zones can be extremely diverse.

Humans have influenced restingas since their occupation by indigenous populations 8,000 years ago (Kneip 1987). However, it was throughout the $20^{\text {th }}$ century that most of the degradation of this ecosystem occurred because of urban growth, 90\% of the restingas have been destroyed at the present time (WWF 2007). Even the regions that are legally 
recognized as protected areas still suffer from fire, sand mining, extraction of ornamental species, urban development, and tourism (Zamith and Scarano 2006). The failure to control these actions led to the reduction of areas within restinga, and in 1999 only $0.63 \%$ (770.65 ha) of the total area of the municipality of Rio de Janeiro was still restinga (PCRJ 2000a). The majority of the remaining habitat is in an accelerated process of degradation, putting a lot of species in threat of local extinction (PCRJ 2000b). For this reason, in 1993 the city government of Rio de Janeiro implemented the project Flora do Litoral, which goals are to restore the degraded restingas and to produce seedlings of native taxa, including threatened species (Zamith and Dalmaso 2000).

Melocactus violaceus Pfeiff. is one of the threatened species in restingas of Rio de Janeiro (PCRJ 2000b). This species is also cited as vulnerable in the states of Espírito Santo (2005) and Pernambuco (Uchoa Neto and Tabarelli 2002), and is on the Red List of the threatened flora published by the International Union for Conservation of Nature (IUCN 2009). The reproduction of Melocactus species in natural habitats occurs exclusively by seeds (Taylor 1991). The reproductive restrictions of $M$. violaceus, the overcollection for ornamental purposes, and the destruction of its habitat are causing this species to disappear from the restingas of the municipality of Rio de Janeiro, where individuals can rarely be found in remnants of Barra da Tijuca and Marambaia (pers. obs.). Illegal extraction has put many other cacti species at risk, and ex situ propagation has been suggested as an alternative for conservation of these species (RojasAréchiga and Vazquez-Yanes 2000, Flores et al. 2006). However, Rojas-Aréchiga and VazquezYanes (2000) pointed out that little is known about the requirements for germination, longevity, and seed viability for taxa in this family, and that there is an urgent need for more studies. Thus, the cultivation of $M$. violaceus from seeds would allow the reintroduction of individuals into less impacted regions and restoration areas, increasing the chances of maintaining and preserving populations (Zamith and Scarano 2004).

Germination is controlled by physical factors of the environment, such as light and temperature, and the combination of these factors directly affects seedling establishment (Baskin and Baskin 1988, Ghersa et al. 1992). However, the influence of these factors varies among plant species (Vázquez-Yanes and Orozco-Segovia 1993) and this information is needed for assessing the germination of seeds preserved in seed banks and to produce seedlings, both important for the conservation of threatened species (Almeida et al. 2009).

Light is an important factor that influences germination. Many cactus seeds are positively photoblastic, and complete darkness can reduce their germination capacity (Rojas-Aréchiga \& VázquezYanes 2000, Flores et al. 2006, 2011). Seeds of $M$. violaceus are positively photoblastic (unpublished data), which has also been observed for the seeds of M. conoideus (Rebouças and Santos 2007), and require light to germinate. This requirement is common among species with small seeds that have small reserves, reducing the probability of germination when the seeds are buried in the soil (Pons 2000, Zaidan and Barbedo 2004).

Among species of Cactaceae, a wide response to temperature has been observed (Rizzini 1982, Lucas and Frigeri 1990, Nolasco et al. 1996, Rojas-Aréchiga et al. 2001, Ramírez-Padilla and Valverde 2005, Méndez 2007, Simão et al. 2007), and frequently the effects of constant and alternating temperatures on cacti seed germination show contradictions between different species (Ortega-Baes et al. 2011). In a review article, RojasAréchiga and Vasquez-Yanes (2000) observed that a temperature of $20 \pm 2{ }^{\circ} \mathrm{C}$ gives a good germination rate in a wide range of genera and alternating temperatures give better germination results than constant temperatures. However, the authors mentioned that in some experiments alternating 
temperatures regime did not show significant differences when compared to treatments kept at a constant temperature, and that whenever there were significant differences they were related to a lower constant temperature (around $17^{\circ} \mathrm{C}$ ) (GodínezAlvarez and Valiente-Banuet 1998).

The aim of this study was to test the effect of different temperature ranges on the germination of the $M$. violaceus seeds and identify the conditions that are most adequate for the production of seedlings that will be reintroduced into protected areas. Until this study, the temperature range needed for the germination of $M$. violaceus was not known.

\section{MATERIALS AND METHODS}

Melocactus violaceus, commonly known as corôa-de-frade in Brazil, grows in the states of Rio Grande do Norte, Paraíba, Pernambuco (Zickel et al. 2007), Sergipe, in the rupestrian fields of Chapada Diamantina in Bahia (Alves et al. 2007), Minas Gerais, Espírito Santo, and Rio de Janeiro (Taylor 1991). The subspecies that grows in the restinga from Rio de Janeiro to Rio Grande do Norte is Melocactus violaceus subsp. violaceus, and can also be found up to $1,100 \mathrm{~m}$ elevation in the cerrado of Minas Gerais (Taylor 1991). This subspecies has a depress-globose, hemispheric, or disc-shaped stem that is 6 to 16 $\mathrm{cm}$ in diameter, with 6 to 12 spines per areole, pinkish flowers measuring $25 \times 13.5 \mathrm{~mm}$, pinkish fruits measuring $12.5-19 \times 5.5-7.5 \mathrm{~mm}$, and seeds measuring 1.2-1.5 × 1.0-1.4 mm (Taylor 1991). In restinga, $M$. violaceus typically grows in open, non-flooded shrubland, exposed to the sun (Freitas 1990, Côrtes Figueira et al. 1994), and does not survive in heavily shaded areas (pers. obs.).

Fruits of M. violaceus were collected in May 2001 from 60 individuals kept at Horto Carlos Toledo Rizzini (22 $59^{\prime}$ 'S, $43^{\circ} 22^{\prime} \mathrm{W}$ ), which houses the headquarters of project Flora do Litoral. The individuals came from plants that were illegally harvested from restingas in the state of Rio de
Janeiro and were seized by the Instituto Brasileiro do Meio Ambiente e dos Recursos Naturais (IBAMA). In nurseries, individuals of this species produce flowers and fruits throughout the year (Zamith and Scarano 2004).

The seeds were manually removed from the fruits using running water and were dried and stored in plastic bags for six months, at room temperature. After storage the seeds were disinfected using a sodium hypochlorite solution (15\%) for 10 minutes and then washed with distilled water. The seeds were placed in plastic square boxes $(11 \times 11 \times 3.5$ $\mathrm{cm}$ ) on top of restinga sand that had been sterilized for two hours at $150^{\circ} \mathrm{C}$.

Three treatments were used to investigate the effect of temperature on seed germination: a constant temperature of $25^{\circ} \mathrm{C}$; an alternating temperature of 20-35 ${ }^{\circ} \mathrm{C}$; and a temperature that varied based on room temperature (RT), ranging between $24-41^{\circ} \mathrm{C}$ with a minimum mean of $25 \pm 1^{\circ} \mathrm{C}$ and a maximum mean of $37 \pm 0.8^{\circ} \mathrm{C}$. The first two treatments were conducted in germination chambers (J. Prolab Ind. e Com. de Produtos para Laboratório Ltda., Model JP 1000, Brazil and Eletrolab Ind. e Com. de Equipamentos para Laboratório Ltda., Model EL 212, Brazil), and the third treatment was kept on a lab bench, under a light intensity of 1,154 lux, produced by white light, similar to the light produced by the germination chamber. All treatments had a photoperiod of 12 hours. The experimental design was entirely random. Four replicates per treatment were made using 50 seeds per replicate. Seed germination that started with the protrusion of the radicle was observed for 63 days. Each treatment was watered, and newly germinated seeds were counted, every two to four days.

For the statistical analysis, the values for the germination percentage were transformed into arcsine $\sqrt{ } \% / 100$ and submitted to variance analysis. When a significant difference was found by the $\mathrm{F}$ test, the mean was compared using Tukey's test at the probability level of 5\% (Zar 1999). The germination speed index 
(GSI) was obtained from the formula proposed by Maguire (1962): GSI $=\mathrm{G}_{1} / \mathrm{N}_{1}+\mathrm{G}_{2} / \mathrm{N}_{2}+\ldots+\mathrm{G}_{\mathrm{n}} / \mathrm{N}_{\mathrm{n}}$, where: $G_{1}, G_{2}$, and $G$ are the numbers of germinated seeds on the first, second, and last count; and $\mathrm{N}_{1}, \mathrm{~N}_{2}$, and $\mathrm{N}_{\mathrm{n}}$ are the numbers of days between the count and the beginning of the experiment.

Additionally, in September 2002, based on the results obtained from the three treatments, another treatment was conducted under a constant temperature of $35^{\circ} \mathrm{C}$. The aim of this treatment was to evaluate the effect of a higher constant temperature on germination. The seeds used in this treatment were stored for six months, as done for the seeds used in original treatments. Due to a lack of seeds, four replicates were made with 25 seeds each. This treatment was conducted in a germination chamber and watered every two to four days.

\section{RESULTS}

The time course of germination at different temperatures (Fig. 1) followed a typical sigmoid curve. At the alternating temperatures $\left(20-35^{\circ} \mathrm{C}\right.$ and RT treatments), the lag time to onset of germination was ca. seven days. The constant temperature retarded germination by increasing the lag time (10 days), reducing the germination rate and lowering the final germination percentage. At the end of 63 days, no germination was observed among treatments.

The highest percentages of germination were obtained by exposing the seeds to alternating temperatures that promoted statistically higher germination percentage $(\mathrm{F}=18.94, \mathrm{df}=2, \mathrm{p}<0.001)$ than to constant temperature (Tab. I). There were no significant differences ( $p>0.05$ ) between the two treatments with alternating temperatures.

The GSI, as well as the germination percent, was significantly different $(F=8.61, d f=2, p<0.01)$ between the treatment kept at a constant temperature and the treatments with alternating temperatures. The GSI was slightly higher for the RT treatment (2.21), but was not statistically different from the 20-35 ${ }^{\circ} \mathrm{C}$ treatment (1.78).

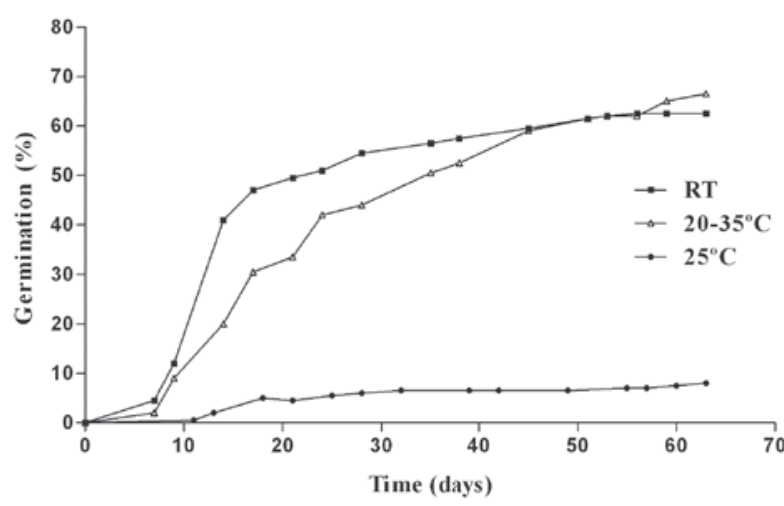

Figure 1 - Means of germination percentages of Melocactus violaceus at three different temperature treatments (alternating temperature between $20-35^{\circ} \mathrm{C}$ and room temperature (RT), and a constant temperature of $25^{\circ} \mathrm{C}$ ) over 63 days.

The time course of germination at constant temperature of $35^{\circ} \mathrm{C}$ (Fig. 2) showed a pattern similar to germination at constant temperature of $25^{\circ} \mathrm{C}$, and the GSI was $0.11 \pm 0.09$.

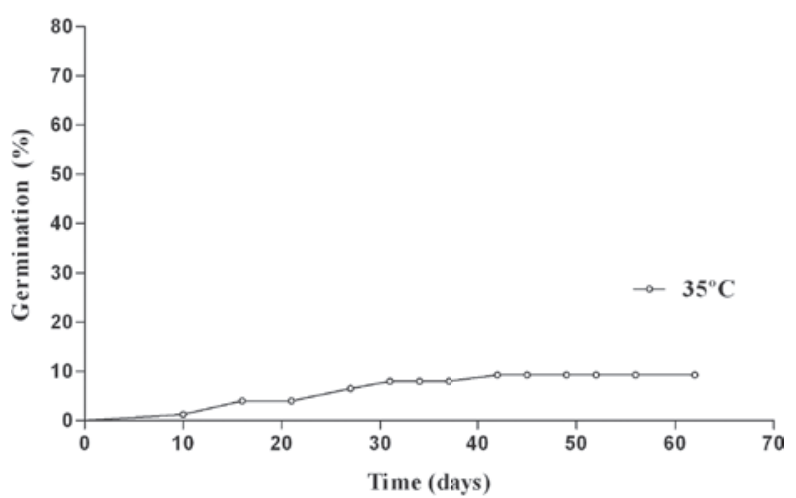

Figure 2 - Means of germination percentages of Melocactus violaceus at constant temperature of $35^{\circ} \mathrm{C}$ over 63 days.

TABLE I

Means ( \pm SD) of germination percentage and germination speed index (GSI) of Melocactus violaceus at three different temperature treatments (alternating temperature between $20-35^{\circ} \mathrm{C}$ and room temperature (RT), and a constant temperature of $25^{\circ} \mathrm{C}$ ). Means were compared by ANOVA and different letters in same column indicate significant differences according Tukey test $(*=\mathbf{p}<0.05 ; * *=\mathbf{p}<0.01$ and $* * *=\mathbf{p}<0.001)$.

\begin{tabular}{ccc}
\hline Treatments & Germination (\%) & GSI \\
\hline $20-35^{\circ} \mathrm{C}$ & $66.5 \pm 18.8 \mathrm{a} * * *$ & $1.78 \pm 1.14 \mathrm{a}^{*}$ \\
$\mathrm{RT}$ & $62.5 \pm 17.9 \mathrm{a} * *$ & $2.21 \pm 0.50 \mathrm{a} * *$ \\
$25^{\circ} \mathrm{C}$ & $8.0 \pm 1.6 \mathrm{~b}$ & $0.20 \pm 0.05 \mathrm{~b}$ \\
\hline
\end{tabular}




\section{DISCUSSION}

Alternating temperatures allowed good germination rates for seeds of $M$. violaceus. In their natural habitat, seeds are exposed to alternating temperatures, which is a more favorable condition for germination compared to a constant temperature (Baskin and Baskin 2001). However, since cactus seedling establishment generally occurs under nurse plants, where the amplitude of soil temperature fluctuations is less extreme (Godínez-Alvarez et al. 2003), OrtegaBaes et al. (2011) suggest that cacti seeds might germinate better under constant temperatures. Recent works on germination of different cacti seeds have reported that alternating temperatures induce, inhibit, or no promote different responses when compared to constant temperatures (Godínez-Alvarez and Valiente-Banuet 1998, Rojas-Aréchiga et al. 1998, Rojas-Aréchiga and Vásquez-Yanes 2000, RamírezPadilla and Valverde 2005, Ortega-Baes and RojasAréchiga 2007, Ortega-Baes et al. 2011), and these results have been attributed to a limited number of temperature regimes tested (Rojas-Aréchiga et al. 1998, Rojas-Aréchiga and Vásquez-Yanes 2000, Ortega-Baes and Rojas-Aréchiga 2007).

In a study with four Brazilian cacti species, Almeida et al. (2009) observed that seeds of these species did not require the alternating temperature regime and constant temperatures were more favorable to germination. Constant temperatures, ranging from 25 to $30^{\circ} \mathrm{C}$, also seem to be efficient to the germination of Cereus jamacaru in areas of Caatinga in the Northeast of Brazil (Meiado et al. 2010).

Variation in seed germination response can occur among species that are closely related, such as the different results found in germination studies that have used species of Melocactus. For example, for M. bahiensis (Britton \& Rose) Luetzelb, which occurs in exposed areas or under or between shrubs, in the rupestrian fields and caatingas of Pernambuco, Bahia, and northern Minas Gerais (Taylor 1991), it was observed that the highest germination percentage occurred when seeds were exposed to a constant temperature of $25^{\circ} \mathrm{C}(48 \%$ and GSI $=3.58$ ), and the seeds did not germinate when the temperature varied between $20-30^{\circ} \mathrm{C}$ (Lone et al. 2007). For M. conoideus Buining \& Brederoo that grows under and between shrubs in high elevation cerrados $(1,050 \mathrm{~m})$ in southeastern Bahia (Taylor 1991), Rebouças and Santos (2007) observed a germination index of approximately $84 \%$ under a constant temperature of $30^{\circ} \mathrm{C}$. Our results for $M$. violaceus, show a significantly higher percentage and speed of germination when seeds were under alternating temperatures, suggesting that this regime is ideal for inducing seed germination of this species. This was confirmed at the end of the experiments, when the seeds used in the treatment at a constant temperature of $25^{\circ} \mathrm{C}$, that did not germinate $(\mathrm{N}=184)$, were submitted to alternating temperatures $\left(20-35^{\circ} \mathrm{C}\right)$. Under this new condition, these seeds began to germinate on the eleventh day, and, after 63 days, $42 \%$ of the seeds germinated (GSI $=2.78 \pm$ $0.17)$. The low percentage and speed of germination obtained under a constant temperature of $35^{\circ} \mathrm{C}$ corroborate that alternating temperature promotes highest germination rate for this species.

Côrtes Figueira et al. (1994) performed laboratory experiments at room temperature to study the effect of saurochory on the germination of M. violaceus seeds. The authors observed that germination rates of seeds that went through the digestive tract of the lizard Tropidurus torquatus Wied were higher than those from seeds collected directly from the fruits. Those results differ from what was found in our study because we observed good germination rates without participation of T. torquatus. In the present study, the germination percentages in the experiments that used variable temperatures $\left(66.5 \%\right.$ under $20-35^{\circ} \mathrm{C}$ and $62.5 \%$ at RT) were higher than the results observed by Côrtes Figueira et al., where the seeds had passed through the intestinal tract of the lizard (mean of 36\%). 
This difference demonstrates that $M$. violaceus seeds are able to germinate without passing through the digestive tract of this species, as long as the temperature and light conditions are adequate. However, the ingestion of fruits by this lizard is important to the ecology and conservation of $M$. violaceus because the lizards act as a seed disperser. Moreover, it is possible that germination experiments with seeds eaten by the lizard and under controlled conditions achieve a higher germination percentage than our results obtained.

The geographic distribution and the ecological preferences of many species are defined, among other factors, by the environmental conditions required for the germination of their seeds (Cuzzuol and Lucas 1999, Ramírez-Padilla and Valverde 2005). Since $M$. violaceus occurs in restinga, exclusively in the open areas among shrubs and exposed to the sun, the temperature variation during the day and night must provide the temperature variation that the seeds need to germinate.

The extraction of Cactaceae species from native habitats, because they are valued as ornamentals, has put many species at risk. Propagation studies can contribute to the conservation of these plants, since the production of seedlings can lower the demand for individuals from natural populations (Rojas-Aréchiga and Vaquez-Yanes 2000). This study showed that alternating temperatures between $20^{\circ} \mathrm{C}$ and $37^{\circ} \mathrm{C}$ provides satisfactory conditions to induce a high percentage of seed germination of M. violaceus. The results obtained during this study will allow us to test the viability and germination of the seeds stored in seed banks for conservation purposes, and will allow for the production of seedlings of this threatened species, making it possible to reintroduce it into protected areas. This will also contribute to reduce the number of individuals collected from the remaining natural populations.

\section{ACKNOWLEDGMENTS}

We are grateful to the anonymous referees for reviewing the manuscript. We would like to thank the interns of project Flora do Litoral that helped with the lab work, and the Fundação Parques e Jardins for logistical support. We would also like to thank TS Pereira and ACS Andrade for their useful comments and review of the manuscript.

\section{RESUMO}

Melocactus violaceus é uma espécie ameaçada devido à destruição de seu habitat e a coleta excessiva para uso como ornamental. O objetivo deste estudo foi testar o efeito de diferentes temperaturas sobre a germinação de $M$. violaceus. Três tratamentos foram conduzidos: temperatura constante de $25^{\circ} \mathrm{C}$, temperatura alternada de $20-35^{\circ} \mathrm{C}$, ambos em câmaras de germinação, e temperatura alternada em condição ambiente (onde a temperatura variou entre $25-37^{\circ} \mathrm{C}$ ). Os percentuais finais de germinação nos tratamentos com temperatura alternada não foram significativamente diferentes ( $65 \%$ na câmara de germinação e $62,5 \%$ na condição ambiente). Entretanto, ambos os tratamentos com temperaturas alternadas tiveram percentuais de germinação significativamente maiores comparados com o tratamento mantido em temperatura constante $(8 \%)$. Nosso estudo mostrou que temperaturas alternadas entre 20 e $37^{\circ} \mathrm{C}$ fornecem condições satisfatórias para induzir um alto percentual de germinação de sementes de $M$. violaceus, sem a passagem das sementes pelo trato digestivo de seu dispersor natural, o lagarto Tropidurus torquatus. Esta condição contribui para a eficiente produção de plântulas desta espécie que podem ser reintroduzidas em unidades de conservação ou usadas como ornamentais, auxiliando na redução da coleta excessiva sobre as populações nativas remanescentes.

Palavras-chave: Cactaceae, conservação, germinação, Melocactus violaceus, restinga, temperatura.

\section{REFERENCES}

ALMEIDA TMH, ANDRADE ACS AND LOPES HM. 2009. Brazilian cacti seed germination under different temperature and substrate conditions. Seed Sci Technol 37: 474-479.

Alves RJV, CARDIN L AND KROPF MS. 2007. Angiosperm disjunction "Campos Rupestres- restingas": a re-evaluation. Acta Bot Bras 21: 675-685. 
BASKIN CC AND BASKIN JM. 1988. Germination ecophysiology of herbaceous plant species in a temperate region. Am J Bot 7: 286-305.

BASKIn CC AND BASKIN JM. 2001. Seeds: Ecology, Biogeography, and Evolution of Dormancy and Germination. San Diego: Academic Press, 666 p.

CôRTes Figueira JE, VAsconcellos-Neto J, Garcia M AND SoUZAAL. 1994. Saurochory in Melocactus violaceus (Cactaceae). Biotropica 26: 295-301.

CUZZUOL GRF AND LuCAS NMC. 1999. Germinação de Matelea maritima (Jack) Woods (Asclepiadaceae). Rev Bras Bot 22: 1-7.

ESPÍRITO SANTO. 2005. Decreto ${ }^{\circ} 1499-R$, de 13 de junho de 2005. Declara as espécies da fauna e flora silvestres ameaçadas de extinção no Estado do Espírito Santo, e dá outras providências. Diário Oficial do Estado do Espírito Santo, Poder Executivo, Vitória, ES, 16 jun.2005, 6 p.

Flores J, JuRAdo E AND ARREDONDO A. 2006. Effect of light on germination of seeds of Cactaceae from the Chihuahan Desert, Mexico. Seed Sci Res 16: 149-155.

FLORES J ET AL. 2011. Seed photoblastism and its relationship with some plant traits in 136 cacti taxa. Environ Exp Bot 71: 79-88.

FREITAS MF. 1990. Cactaceae da área de proteção ambiental da Massambaba, Rio de Janeiro, Brasil. Rodriguésia 42/44: 67-91.

GHERSA CM, BENETH-ARNOLD RL AND MARTINEZ-GHERSA MA. 1992. The role of fluctuating temperatures in germination and establishment of Sorghum hapelense. Regulation of germination at increasing depths. Funct Ecol 6: 460-468.

GodíneZ-Alvarez H And VAliente-BAnUet A. 1998. Germination and early seedling growth of Tehuacan Valley cacti species: the role of soils and seed ingestion by dispersers on seedling growth. J Arid Environ 39: 21-31.

Godínez-Alvarez $\mathrm{H}$, Valverde T and Ortega-Baes P. 2003. Demographic trends in the Cactaceae. Bot Rev 69:173-203.

IUCN - INTERNATIONAL UNION FOR CONSERVATION OF NATURE. 2009. The IUCN red list of threatened species. Available at http://www.iucnredlist.org. accessed in 20/02/2010 (www.redlist.org).

KNEIP LM. 1987. Sambaquis na pré-história do Brasil. Ciência Hoje 6: 50-54.

Lacerda LD, Araujo DSD And Maciel NC. 1993. Dry coastal ecosystems of the tropical Brazilian coast. In: VAN DER MAAREL E (Ed), Ecosystems of the World 2B: dry coastal ecosystems: Africa, America, Asia and Oceania, Amsterdam: Elsevier, p. 477-493.

Lone AB, TAKAhashi LSA, FARIA RT AND UNEMOTO LK. 2007. Germinação de Melocactus bahiensis (Cactaceae) em diferentes substratos e temperaturas. Scientia Agraria 8: 365-369.

LUCAS NMC AND FRIGERI RBC. 1990. Características germinativas das sementes de Pilosocereus arrabidae (Lem.) Byl e Rowl (Cactaceae). In: III Simpósio de Ecossistemas da Costa Sul e Sudeste Brasileira, 1990, São Paulo, Brasil, p. 467-477.
MAGUIRE JD. 1962. Speed of germination aid in selection and evaluation for seedling emergence and vigor. Crop Sci 2: 176-177.

Meiado MC, Albuquerque LSC, Rocha EA, RojasARÉCHIGA M AND LEAL IR. 2010. Seed germination responses of Cereus jamacaru DC. ssp. jamacaru (Cactaceae) to environmental factors. Plant Species Biology 25: 120-128.

MÉNDEZ E. 2007. Germination of Denmoza rhodacantha (Salm-Dyck) Britton \& Rose (Cactaceae). J Arid Environ 68: 678-682.

Myers N, MitTermeier RA, MitTermeier CG, FonseCA GAB AND KENT J. 2000. Biodiversity hotspots for conservation priorities. Nature 403: 853-858.

Nolasco H, Vega-Villasante F, Romero-Schmidt HL AND DíAZ-Rondero A. 1996. The effects of salinity, acidity, light and temperature on the germination of seeds of cardon (Pachycereus pringlei) (S.Wats) Britton \& Rose (Cactaceae). J Arid Environ 33: 87-94.

Ortega-Baes P, Galíndez G, SÜHring S, Rojas-Aréchiga M, DAWS MI AND PRITCHARD HW. 2011. Seed germination of Echinopsis schickendantzii (Cactaceae): the effects of constant and alternating temperatures. Seed Sci Technol 39: 219-224.

Ortega-BAEs P AND RoJAS-ARÉchiga M. 2007. Seed germination of Trichocereus terscheckii (Cactaceae):light, temperature and gibberellic acid effects. J Arid Environ 69: 169-176.

PCRJ/SECRETARIA Municipal De Meio Ambiente. 2000a. Mapeamento e caracterização do uso das terras e cobertura vegetal no município do Rio de Janeiro, entre os anos de 1984 e 1999, Rio de Janeiro: PCRJ/ Secretaria do Meio Ambiente do Município do Rio de Janeiro.

PCRJ/Secretaria Municipal de Meio Ambiente. 2000b. Espécies ameaçadas de extinção no município do Rio de Janeiro: flora e fauna, Rio de Janeiro: PCRJ/ Secretaria do Meio Ambiente do Município do Rio de Janeiro.

PONS TL. 2000. Seeds responses to light. In: FENNER M (Ed), Seeds: the ecology of regeneration in plant communities, UK, CABI Publishing, p. 237-260.

RAMíREZ-PAdilla CA AND VALVERdE T. 2005. Germination responses of three congeneric cactus species (Neobuxbaumia) with differing degrees of rarity. J Arid Environ 61: 333-343.

REBOUÇAS ACM AND SANTOS DL. 2007. Influência do fotoperíodo e qualidade de luz na germinação de sementes de Melocactus conoideus (Cactaceae). Rev Bras Biocienc 5: 900-902.

RizzINI CT. 1979. Tratado de Fitogeografia do Brasil. Aspectos sociológicos e florísticos. V. 2, São Paulo, Hucitec, 374 p.

RIZZINI CT. 1982. Melocactus no Brasil. Rio de Janeiro, IBDFJardim Botânico do Rio de Janeiro, 114 p.

RoJAS-ARÉchiga M, CASAS A AND VAZQUEZ-YANES C. 2001. Seed germination of wild and cultivated Stenocereus stellatus (Cactaceae) from the Tehuacán-Cuicatlán Valley, Central Máxico. J Arid Environ 49: 279-287. 
RoJAS-ARÉCHIGA M AND VAZQUEZ-YANES C. 2000. Cactus seed germination: a review. J Arid Environ 44: 85-104.

ROJAS-ARÉCHIGA M, VÁZQUEZ-YANES C AND OROZCOSEGOVIA A. 1998. Seed response to temperature of Mexican cacti species from two life forms: an ecophysiological interpretation. Plant Ecol 135: 207-214.

SCARANO FR. 2002. Structure, function and floristic relationships of plant communities in stressful habitats marginal to the Brazilian Atlantic Rainforest. Ann BotLondon 90: 517-524.

SIMÃo E, SOKOLOWSKI F AND TAKAKI M. 2007. The epiphytic Cactaceae Hylocereus setaceus (Salm-Dick ex DC.) Ralf Bauer seed germination is controlled by light and temperature. Braz Arch Biol Techn 50: 655-662.

TAYLOR NP. 1991. The genus Melocactus (Cactaceae) in Central and South America. Bradleya 9: 1-80.

UchoA Neto CAM And TABarelli M. 2002. Diagnóstico e Estratégia de Conservação do Centro de Endemismo Pernambuco. Centro de Pesquisas Ambientais do Nordeste- CEPAN. N ${ }^{\circ} \mathrm{CSFY} 02 / 00 X$. Conservation International do Brasil.

VÁZqueZ-Yanes C ANd Orozco-Segovia A. 1993. Patterns of seed longevity and germination in the tropical rain forest. Annu Rev Ecol Syst 24: 69-87.

WWF - WORLD WILDLIFE FUND (CONTENT PARTNER), MARK MCGINLEY (TOPIC EDITOR). 2007. Atlantic Coast restingas. In: CUTLER J (Ed), Encyclopedia of Earth. Cleveland, Washington, D.C. http://www.eoearth.org/ article/Atlantic_Coast_restingas accessed in 15/09/2008.
ZAIDAN LBP AND BARBEDO CJ. 2004. Quebra de dormência em sementes. In FERREIRA AG AND BORGHETTI F (Eds), Germinação: do básico ao aplicado, Porto Alegre, Artmed, p. 135-148.

ZAMITH LR AND DALMASO V. 2000. Revegetação de restingas degradadas no município do Rio de Janeiro, RJ. In: V Simpósio de Ecossistemas Brasileiros: Conservação, Vitória, Anais do V Simpósio de Ecossistemas Brasileiros: Conservação n. ${ }^{\circ} 105$ V. IV, Vitória: Aciesp, p. 227-234.

ZAMITH LR AND SCARANO FR. 2004. Produção de mudas de espécies das restingas do município do Rio de Janeiro, RJ, Brasil. Acta Bot Bras 18: 161-176.

ZAMITH LR AND SCARANO FR 2006. Restoration of a restinga sandy coastal plain in Brazil: survival and growth of planted woody species. Restor Ecol 14: 87-94.

ZAR JH. 1999. Biostatistical Analysis, $4^{\text {th }}$ ed., Upper Saddle River, NJ, Prentice-Hall, 662 p.

Zickel CS, Almeida Jr EB, Medeiros DPW, Lima PB, SOUZA TMS AND BARROS AL. 2007. Magnoliophyta species of restinga, Pernambuco State, Brazil. In Check List v. 3, São Paulo, UNESP, p. 224-241. 